\title{
PERSEPSI PESERTA DIDIK TERHADAP 10 KETERAMPILAN MENGAJAR GURU BIOLOGI PRAKTEK LAPANGAN (PL) DI SMAN 1 BUKITTINGGI
}

\author{
(Perception Students'of The 10 Teachers Teaching Skills Of Biology Field Practice At \\ SMAN 1 Bukittinggi)
}

\author{
Fitri Wijayanti*) Ennike Gusti Rahmi, M.Pd**) \\ ennikerahmi@gmail.com
}

*) Mahasiswa STKIP Ahlussunnah Bukittinggi

**) Dosen STKIP Ahlussunnah Bukittinggi

\begin{abstract}
The purpose of this study was to find out students' perception of the teaching skills of field practice biology teachers (PL) at SMAN 1 Bukittinggi. This research is descriptive research. The sampling technique used is Random Sampling, where each class is sampled for $20 \%$ of the total number of students. Thus from the population of mipa students in grade X and XI SMAN 1 Bukittinggi amounted to 273 students spread across 8 locally, sampled by $20 \%$ of 56 students. The data obtained is processed using percentage technique (\%). Based on the analysis of data obtained from the results of the study, it is known that students' perception of the teaching skills of field practice biology teachers in SMAN 1 as a whole is good with a percentage of $82.25 \%$. While reviewed from each sub-variable described as follows: 1) Skills of opening and closing learning with a percentage of $85.14 \%$, good category; 2) Skills managing classes with a percentage of $77,68 \%$, category is quite good; 3) Reinforcement skills with a percentage of 74,25\%, the category is quite good; 4) Skills guiding small group discussions with a percentage of 79,51\%, a pretty good category; 5) Questioning skills with a percentage of $82.71 \%$, good category; 6) Skill explaining with percentage 81.28, good category; 7) Skills held variasai with a percentage of $79.21 \%$, the category is quite good; 8) Teaching skills of small groups and individuals with a percentage of 78,20\%, the category is quite good; 9) Skills to develop and use learning media with a percentage of $82.42 \%$, good category; 10) Esq developing skills with a percentage of $78.42 \%$, the category is quite good.
\end{abstract}

Key words:Perception, Field Practice, and Teaching Skills.

\section{Abstrak}

Tujuan penelitian ini adalah untuk mengetahui persepsi siswa terhadap kemampuan mengajar guru biologi praktik lapangan (PL) di SMAN 1 Bukittinggi. Penelitian ini adalah penelitian deskriptif. Teknik pengambilan sampel yang digunakan adalah Random Sampling, di mana setiap kelas diambil sebesar 20\% dari total jumlah siswa. Dengan demikian dari populasi siswa MIPA kelas X dan XI SMAN 1 Bukittinggi berjumlah 273 siswa yang tersebar di 8 lokal, diambil sebesar $20 \%$ dari 56 siswa. Data yang diperoleh diproses menggunakan teknik persentase (\%). Berdasarkan analisis data yang diperoleh dari hasil penelitian, diketahui bahwa persepsi siswa terhadap kemampuan mengajar guru biologi praktik lapangan di SMAN 1 secara keseluruhan baik dengan persentase $82,25 \%$. Sementara ditinjau dari setiap sub variabel yang dijelaskan sebagai berikut: 1) Keterampilan membuka dan menutup pembelajaran dengan persentase $85,14 \%$, kategori baik; 2) Keterampilan mengelola kelas dengan persentase $77,68 \%$, kategori cukup baik; 3) Keterampilan penguatan 
dengan persentase $74,25 \%$, kategorinya cukup baik; 4) Keterampilan membimbing diskusi kelompok kecil dengan persentase $79,51 \%$, kategori yang cukup bagus; 5) Keterampilan mempertanyakan dengan persentase 82,71\%, kategori baik; 6) Keterampilan menjelaskan dengan persentase 81,28, kategori baik; 7) Keterampilan diadakan variasai dengan persentase 79,21\%, kategorinya cukup baik; 8) Keterampilan mengajar kelompok kecil dan individu dengan persentase 78,20\%, kategorinya cukup baik; 9) Keterampilan untuk mengembangkan dan menggunakan media pembelajaran dengan persentase $82,42 \%$, kategori yang baik; 10) ESQ mengembangkan skill dengan persentase $78,42 \%$, kategorinya cukup bagus.

Kata kunci: Persepsi, Praktek Lapangan, dan Keterampilan Mengajar.

\section{PENDAHULUAN}

Pendidikan Salah satu tujuan nasional bangsa Indonesia yang tercantum dalam Undang-Undang Dasar 1945 adalah mencerdaskan kehidupan bangsa untuk itu perlu adanya peran aktif dari seluruh komponen bangsa agar tujuan tersebut dapat tercapai. Untuk mewujudkan tujuan tersebut calon guru diharuskan memiliki pengetahuan dan keterampilan dalam mengajar.

Sebagai salah satu perguruan tinggi yang menyelenggarakan pendidikan keguruan STKIP Ahlussunah Bukittinggi terus berupaya menyiapkan guru yang berkualitas dan profesional pada bidangnya sehingga dapat memenuhi tuntutan dunia pendidikan.

Dalam menyiapkan tenaga pendidik yang profesional para mahasiswa STKIP Ahlussunnah Bukittinggi wajib mengikuti proses kegiatan Praktik Lapangan (PL). Praktik lapangan bertujuan membentuk mahasiswa agar menjadi calon tenaga pendidik yang profesional.

Keberhasilan dalam melaksanakan PL ini tidak hanya berdampak pada mahasiswa itu sendiri tetapi juga dirasakan oleh siswa yang merupakan peserta didik. Seorang guru jika mempunyai kemampuan mengajar yang baik akan dapat melaksanakan pembelajaran dari awal sampai akhir dengan baik pula. Mahasiswa yang melaksanakan PL harus benar-benar mampu melaksanakan proses pembelajaran dan memiliki kemampuan mengajar dengan baik. Apabila mahasiswa belum layak untuk melaksanakan PL dapat berdampak buruk bagi siswa terutama untuk masa depan siswa tersebut.

Berdasarkan pengalaman peneliti saat praktek lapangan (PL) pada tanggal 7 Agustus sampai dengan 20 Desember 2019 di SMAN 1 Bukittinggi, yaitu diketahui bahwa dalam melakukan kegiatan PL banyak hal yang harus dihadapi oleh mahasiswa diantaranya: mahasiswa PL dalam kegiatan pembelajaran akan selalu diamati, diperhatikan, didengar, ditiru dan bahkan dinilai siswa mengenai penampilan dikelas. Saat kegiatan pembelajaran dikelas siswa yang menyenangi pelajaran yang diberikan oleh mahasiswa PL akan rajin untuk mempelajarinnya,

Saat kegiatan pembelajaran berlangsung ditunjukkan dalam perilaku belajar yang baik misalnya memperhatikan materi yang diberikan oleh mahasiswa PL, ikut berpartisipasi aktif dalam kegiatan pembelajaran, mau bertanya dan senang mengerjakan tugas. Sedangkan siswa yang tidak menyukai pelajaran yang diberikan oleh mahasiswa PL akan telat masuk kelas, sibuk dengan diri sendiri, menganggu temantemannya, malas mengerjakan tugas, sering izin keluar kelas bahkan meremehkan mahasiswa PL. Tujuan penelitian ini adalah untuk mengetahui persepsi siswa terhadap kemampuan mengajar guru biologi praktik lapangan (PL) di SMAN 1 Bukittinggi. Berdasarkan uraian diatas, agar program praktek lapangan (PL) 
selanjutnya dapat berjalan efektif dengan peningkatan keterampilan mengajar dan meningkatkan kepercayaan masyarakat terhadap kualitas lulusan STKIP Ahlussunnah Bukittinggi, maka perlu dilakukan penelitian mengenai persepsi peserta didik terhadap keterampilan mengajar mahasiswa praktek lapangan (PL) Prodi Biologi STKIP Ahlussunnah Bukittinggi agar dapat digunakan sebagai tolak ukur keberhasilan PL baik secara personal maupun lembaga pendidikan.

\section{METODE PENELITIAN}

Jenis penelitian yang digunakan adalah deskriptif. Penelitian deskriptif menurut Arikunto (2014) adalah "penelitian yang memaparkan atau mengambarkan sesuatu hal.Penelitian ini telah dilakukan di SMAN 1 Bukittinggi.Waktu pelaksanaan penelitian adalah pada semester genap .

Pengambilan sampel pada penelitian ini dilakukan dengan teknik Random Sampling yaitu sampel yang diambil secara acak tanpa memperhatikan strata yang ada dalam populasi. Populasi siswa MIPA kelas X dan XI SMAN 1 Bukittinggi berjumlah 273 orang siswa yang tersebar dalam 8 lokal, diambil sampel sebesar $20 \%$ yaitu 56 orang siswa.

Secara umum prosedur penelitian dapat dibagi dalam tiga tahap yaitu tahap persiapan, tahap pelaksanaan, dan tahap penyelesaian.

1. Tahap Persiapan

a. Melakukan observasi

b. Menyusun proposal penelitian

c. Bimbingan proposal penelitian

d. Seminar proposal

e. Perbaikan proposal untuk penelitian

f. Mengurus surat izin penelitian dari kampus STKIP Ahlussunnah Bukittinggi.

g. Meminta izin kepada kepala SMAN 1 Bukittinggi untuk melakukan penelitian. h. Menemui guru biologi yang mengajar di kelas X dan XI untuk meminta izin melakukan penelitian.

2. Tahap Pelaksanaan

a. Menyebarkan angket dan melakukan wawancara kepada responden

b. Mengumpulkan kembali angket yang disebarkan

3. Tahap Penyelesaian

a. Mengelola data angket dan wawancara penelitian

b. Menarik kesimpulan

Teknik pengumpulan data berupa angket, wawancara, dan dokumentasi.

Teknik Pengolahan Data

Teknik pengolahan data pada angket adalah teknik presentase (\%) menurut Purwanto (2006) menggunakan rumus sebagai berikut.

$$
S=\frac{R}{N} \times 100 \%
$$

Keterangan :

S : Skor yang diharapkan

$\mathrm{R}$ : Jumlah skor dari item atau soal yang dianggap benar

$\mathrm{N}$ : Skor maksimal dari tes tersebut

100\% : Angka ketetapan untuk presentase

Kemudian presentase (\%) ditafsirkan sebagai berikut :

$90 \%-100 \%=$ Sangat baik

$80 \%-89 \%=$ Baik

$65 \%-79 \%=$ Cukup Baik

$55 \%-64 \%=$ Kurang Baik

$<55=$ Tidak lulus atau gagal

\section{HASIL}

Berdasarkan hasil penelitian yang didapat setelah dilakukan pengolahan data dengan menggunakan teknik presentase (\%)dilihat dari jawaban angket responden dan analisis data. Data hasil penelitian yang diperoleh 
dari angket dapat dilihat pada tabel 1

sebagai

berikut:

Tabel 3. Pengelompokkan Data Hasil Penelitian Berdasarkan Variabel

\begin{tabular}{|c|c|c|c|c|c|c|}
\hline No & \begin{tabular}{|c|} 
Item \\
Instrumen
\end{tabular} & $\begin{array}{c}\text { Sub } \\
\text { Variabel }\end{array}$ & \begin{tabular}{|c|} 
Jumlah Skor \\
Item (R)
\end{tabular} & \begin{tabular}{|c|} 
Jumlah Skor \\
Maksimal (N) \\
\end{tabular} & $\begin{array}{c}\text { Presentase } \\
(\%)\end{array}$ & Kategori \\
\hline 1 & $1-5$ & $\begin{array}{l}\text { Keterampilan Membuka } \\
\text { dan Menutup Pelajaran }\end{array}$ & 1192 & 1400 & $85,14 \%$ & Baik \\
\hline 2 & $6-10$ & $\begin{array}{l}\text { Keterampilan Mengelola } \\
\text { Kelas }\end{array}$ & 1060 & 1400 & $77,68 \%$ & $\begin{array}{l}\text { Cukup } \\
\text { Baik }\end{array}$ \\
\hline 3 & $11-15$ & Keterampilan Penguatan & 1043 & 1400 & $74,25 \%$ & $\begin{array}{l}\text { Cukup } \\
\text { Baik }\end{array}$ \\
\hline 4 & $16-20$ & $\begin{array}{l}\text { Keterampilan } \\
\text { Membimbing Diskusi } \\
\text { Kelompok Kecil }\end{array}$ & 1113 & 1400 & $79,51 \%$ & $\begin{array}{l}\text { Cukup } \\
\text { Baik }\end{array}$ \\
\hline 5 & $21-25$ & Keterampilan Bertanya & 1158 & 1400 & $82,71 \%$ & Baik \\
\hline 6 & $26-30$ & Keterampilan Menjelaskan & 1138 & 1400 & $81,28 \%$ & Baik \\
\hline 7 & $31-35$ & $\begin{array}{l}\text { Keterampilan } \\
\text { Mengadakan Variasi }\end{array}$ & 1109 & 1400 & $79,21 \%$ & $\begin{array}{l}\text { Cukup } \\
\text { Baik }\end{array}$ \\
\hline 8 & $36-40$ & $\begin{array}{l}\text { Keterampilan Mengajar } \\
\text { Kelompok Kecil dan } \\
\text { Perorangan }\end{array}$ & 1094 & 1400 & $78,20 \%$ & $\begin{array}{l}\text { Cukup } \\
\text { Baik }\end{array}$ \\
\hline 9 & $41-45$ & $\begin{array}{l}\text { Keterampilan } \\
\text { Pengembangan dan } \\
\text { Menggunakan Media } \\
\text { Pembelajaran }\end{array}$ & 1196 & 1400 & $85,42 \%$ & Baik \\
\hline 10 & $46-50$ & $\begin{array}{l}\text { Keterampilan } \\
\text { Mengembangkan ESQ }\end{array}$ & 1098 & 1400 & $78,42 \%$ & $\begin{array}{l}\text { Cukup } \\
\text { Baik }\end{array}$ \\
\hline \multicolumn{3}{|c|}{$\begin{array}{l}\text { Persepsi Peserta didik Terhadap } \\
\text { Keterampilan Mengajar Guru Biologi } \\
\text { Praktek Lapangan (PL) di SMAN } 1 \\
\text { Bukittinggi }\end{array}$} & 11128 & 14000 & $82,25 \%$ & Baik \\
\hline
\end{tabular}

Berdasarkan data hasil penelitian pada tabel di atas, maka dapat diketahui hasil penelitian ini memiliki dua kategori yaitu baik dan cukup baik.

\section{PEMBAHASAN}

Berdasarkan data hasil penelitian menggunakan angket dari 10 keterampilan mengajar guru, terdapat 2 kategori persepsi siswa yaitu baik dan cukup baik.Untuk kategori baik berada dalam rentang $80-89 \%$.Sedangkan untuk kategori cukup baik berada dalam rentang $65-79 \%$. Pembahasan dari data hasil penelitian mengenai persepsi peserta didik terhadap keterampilan guru biologi praktek lapangan di SMAN 1 Bukittinggi ditinjau dari masing-masing sub variabel dapat dijelaskan sebagai berikut:
1. Keterampilan Membuka dan menutup Pembelajaran

Berdasarkan hasil penelitian pengumpulan data menggunakan angket yang telah dilakukan, keterampilanmembuka dan menutup pelajaran guru

biologi praktek lapangan yaitu $85,14 \%$, kategori "baik". Hasil penelitian menunjukkan bahwa guru praktek lapangan sudah memiliki kemampuan yang baik dalam menarik perhatian siswa sehingga memungkinkan siswa siap secara mental untuk mengikuti kegiatan pembelajaran dan memberikan kesimpulan pada materi yang diajarkan di akhir pelajaran.

2. Keterampilan Mengelola Kelas Berdasarkan hasil penelitian pengumpulan data menggunakan 
angket yang telah dilakukan, keterampilan mengelola kelas yaitu $77,68 \%$, kategori “cukup baik".Hal ini dikarenakan guru praktek lapangan dinilai cukup baik menciptakan kondisi hangat dalam mengajar, cukup baik dalam menegur dan memberikan hukuman kepada siswa yang membuat masalah di kelas dan guru praktek lapangan cukup tepat waktu dalam membuka dan menutup pelajaran.

Bila dikaitakan dengan hasil penelitian diatas keberhasilan guru dalam pembelajaran, di samping ditentukan oleh pengetahuan tentang bahan ajar dan metode mengaiar juga ditentukan oleh pengelolalan kelas.Pengelolaan kelas menurut Syahril, 2009 adalah keterampilan guru untuk menciptakan dan memelihara kondisi belajar yang optimal dan mengembalikannya bila terjadi gangguan dalam proses belajar mengajar

\section{Keterampilan Penguatan}

Berdasarkan hasil penelitian pengumpulan data menggunakan angket yang telah dilakukan, keterampilan penguatan yaitu $74,25 \%$. kategori "cukup baik". Hal ini disebabkan guru praktek lapangan cukup baik memberikan penguatan sebagai tanda persetujuan terhadap tingkah laku atau jawaban siswa yang dinyatakan dalam kata-kata pujian, anggukan atau acungan jempol.

Memberikan

penguatan mempunyai andil untuk meningkatkan hasil belajar siswa karena dengan memberikan penguatan siswa merasa termotivasi lagi untuk menjadi lebih baik sehingga dapat mengembangkan hasil belajar."Penguatan yaitu respon terhadap suatu tingkah laku yang dapat meningkatkan kemungkinan berulangnya kembali tingkah laku tersebut. Tindakan tersebut dimaksudkan untuk memberikan ganjaran atau membesarkan hati siswa agar mereka lebih giat berpartisipasi dalam interaksi pembelajaran"(Syahril, 2009).

4. Keterampilan Membimbing Diskusi Kelompok Kecil

Berdasarkan hasil penelitian pengumpulan data menggunakan angket yang telah dilakukan, keterampilan membimbing diskusi kelompok kecil yaitu 79,51\%, kategori "cukup baik". Hal tersebut membuktikan bahwa guru praktek lapangan dinilai memiliki kemampuan yang cukup baik dalam merumuskan topik yang akan didiskusikan, memberikan bimbingan dan arahan dalam diskusi kelompok agar tetap menuju masalah yang dituju, meminta tanggapan siswa saat diskusi, memberikan kesimpulan diakhir diskusi dan menilai proses diskusi yang telah dilakukan.

Membimbing diskusi kelompok kecil diharapkan mampu membuat siswa lebih aktif, memberikan rasa tanggung jawab dan berfikir kreatif.(Purwanto, 2006) membimbing diskusi kelompok kecil adalah "Siswa beriskusi dalam kelompok-kelompok kecil di bawah pembinaan guru atau temanya untuk berbagai informasi, pemecahan masalah atau pengambilan keputusan, dilaksaanakan dalam suasana terbuka".

\section{Keterampilan Bertanya}

Berdasarkan hasil penelitian pengumpulan data menggunakan angket yang telah dilakukan, keterampilan bertanya yaitu $82,71 \%$. kategori "baik". Hasil penelitian menunjukkan bahwa guru praktek lapangan baik dalam menyampaikan pertanyaan atas materi yang disampaikan, sehingga pertanyaan yang disampaikan mendapatkan balikan yang dikehendaki dan pertanyaan mudah dimengerti oleh siswa selain itu guru praktek lapangan juga dinilai baik dalam membuat siswa 
aktif pada pembelajaran yang diwujudkan melalui keberanian siswa dalam berpendapat.

Keterampilan bertanya menurut Syahril, 2009merupakan kemampuan yang dimungkinkan untuk mendapatkan jawaban balikan dari orang lain. Hal ini berarti keterampilan bertanya berkaitan dengan respon atau tanggapan siswa terhadap guru.

\section{Keterampilan Menjelaskan}

Berdasarkan hasil penelitian pengumpulan data menggunakan angket yang telah dilakukan, keterampilan menjelaskan yaitu $81,28 \%$, kategori "baik". Hasil penelitian menunjukkan bahwa guru praktek lapangan dinilai baik dalam menyajikan pembelajaran yang diorganisasikan secara sistematis, menjelaskan menggunakan bahasa yang mudah dipahami, menguasai materi pelajaran dan memberikan penekanan terhadap materi yang penting agar siswa lebih mudah mengingatnya.

Menjelaskan menurut Darmadi (2010) merupakan "Mengacu kepada perbuatan mengorganisasikan materi pelajaran dalam tata urutan yang terencana dan sistematis sehingga dalam penyajiannya siswa dengan mudah memahaminya".

7. Keterampilan Mengadakan Variasi

Berdasarkan hasil penelitian pengumpulan data menggunakan angket yang telah dilakukan, keterampilan mengadakan variasi yaitu 79,21\%, kategori "cukup baik". Hasil penelitian menunjukkan bahwa guru praktek lapangan dinilai memiliki kemampuan yang cukup baik dalam memberikan variasi saat pembelajaran, sehingga membuat siswa tidak jenuh, variasi tersebut dapat berupa suara, gerakan, pandangan, media pembelajaran, sumber belajar, aktivitas kelas, dan metode pembelajaran.
Keterampilan mengadakan variasi menurut Asril (2011), adalah "Suatu kegiatan guru dalam konteks proses interaksi pembelajaran yang ditunjukkan untuk mengatasi kebosanan peserta didik, sehingga dalam proses situasi pembelajaran senantiasa menunjukkan ketekunan dan penuh partisipasi, inti tujuan proses pembelajaran variasi adalah menumbuh kembangkan perhatian dan minat peserta didik agar belajar lebih baik".

8. Keterampilan Mengajar Kelompok Kecil dan Perorangan

Berdasarkan hasil penelitian pengumpulan data menggunakan angket yang telah dilakukan, keterampilan mengajar kelompok kecil dan perorangan yaitu $78,20 \%$, kategori "cukup baik". Hal tersebut membuktikan bahwa guru praktek lapangan dinilai memiliki kemampuan cukup baik dalam membagi siswa kedalam beberapa kelompok dengan kemampuan yang bervariasi, memberikan bimbingan dan arahan dalam diskusi kelompok agar tetap menuju masalah yang dituju, guru praktek lapangan juga dinilai cukup terampil dalam memberikan kesempatan semua siswa untuk berpartisipasi agar tidak terjadi monopoli pembicaraan (tidak terlalu didominasi pembicaraan, dan tidak terlalu pasif).

Salah satu cara untuk meningkatkan keaktifan siswa dalam pembelajaran adalah dengan mengajar kelompok kecil dan perorangan. Keterampilan mengajar kelompok kecil dan perorangan menurut Lufri, dkk (2006), merupakan "keterampilan guru mengaktifkan siswa belajar dalam bentuk kelompok dan perorangan sehingga pembelajaran berjalan optimal". 
9. Keterampilan Pengembangan dan Menggunakan Media

Berdasarkan hasil penelitian pengumpulan data menggunakan angket yang telah dilakukan, keterampilan pengembangan dan menggunakan media yaitu $82,42 \%$, kategori "baik".Hal tersebut membuktikan bahwa guru praktek lapangan dinilai memiliki kemampuan yang baik dalam mengembangkan dan menggunakan media pembelajaran seperti saat menjelaskan pelajaran guru praktek lapangan tidak hanya menggunakan buku paket saja tetapi menggunakan sumber lain yang berkaitan dengan pokok pembahasan.

Keterampilan pengembangan dan menggunakan media pembelajaran menurut Lufri, dkk (2006) adalah "keterampilan guru dalam merancang atau menciptakan atau memodifikasi media sederhana dan membuat software media elektronik atau multimedia, serta mengimplementasikannya dalam pembelajaran".

10. Keterampilan Mengembangkan ESQ

Berdasarkan hasil penelitian pengumpulan data menggunakan angket yang telah dilakukan, keterampilan mengembangkan ESQ yaitu 78,42\%, "cukup baik". Hal tersebut membuktikan bahwa guru praktek lapangan dinilai memiliki kemampuan cukup baik dalam memberikan bimbingan dan arahan dalam mengembangkan kecerdasan hati, seperti: ketangguhan, inisiatif, optimisme, kemampuan beradaptasi. Mengembangkan kemampuan siswa untuk menjadikan seluruh aktivitas hidupnya sebagai ibadah dan kemampuan siswa untuk menyerap ilmu pengetahuan sebanyakbanyaknya.
Kesuksesan siswa dalam belajar tidak hanya dilihat dari kecerdasan intelektual saja tetapi juga dari kecerdasan emosional dan spiritual."Kecerdasan intelektual (IQ), yaitu menyerap ilmu pengetahuan sebanyak-banyaknya, tapi belum banyak menyentuh kecerdasan emosional dan spiritual.Kecerdasan emosional (EQ) merupakan kemampuan seseorang bersikap dan bertindak secara bijak.Kecerdasan spiritual (SQ) merupakan kemampuan seseorang untuk menjadikan seluruh aktivitas hidupnyaa sebagai ibadah" (Lufri, dkk. 2006).

\section{IMPLIKASI}

Hasil analisis penelitian yang telah dilaksanakan dapat diambil kesimpulan bahwa :

1. Keterampilan membuka dan menutup pembelajaran dengan presentase $85,14 \%$,kategori baik.

2. Keterampilan mengelola kelas dengan presentase $77,68 \%$, kategori cukup baik.

3. Keterampilan penguatan dengan presentase $74,25 \%$, kategori cukup baik.

4. Keterampilan membimbing diskusi kelompok kecil dengan presentase $79,51 \%$, kategori cukup baik.

5. Keterampilan bertanya dengan presentase 82,71\%, kategori baik.

6. Keterampilan menjelaskan dengan presentase 81,28, kategori baik.

7. Keterampilan mengadakan variasai dengan presentase $79,21 \%$,kategori cukup baik.

8. Keterampilan mengajar kelompok kecil dan perorangan dengan presentase $78,20 \%$, kategori cukup baik.

9. Keterampilan mengembangkan dan menggunakan media pembelajaran dengan presentase $82,42 \%$, kategori baik.

10. Keterampilan mengembangkan ESQ dengan presentase $78,42 \%$, kategori cukup baik. 


\section{REFERENSI}

Arikunto, Suharsimi. 2014. Prosedur

Penelitian. Jakarta: Rineka Cipta.

Asril, Zainal. 2011. Micro Teaching

(Disertai dengan pedoman pengalaman lapangan). Jakarta: Rajawali Press.

Darmadi, Hamid. 2012. Kemampuan Dasar Mengajar. Bandung : Alfabeta.

Lufri.Arlis.Yunus dan Sudirman. 2006. Strategi Pembelajaran Biologi. Padang:Jurusan Biologi FMIPA Universitas Negeri Padang.

Purwanto, Ngalim. 2006. Prinsip-prinsip dan Teknik Evaluasi Pengajaran.Bandung : PT. Remaja Rosdakarya

Syahril dan Ilyas. 2009. Profesi Kependidikaan. Padang : UNP Press 